\title{
Integrity in higher education marketing and misleading claims in the university prospectus: what happened next... and is it enough?
}

John Bradley(D)

Correspondence: john.bradley. home@gmail.com

The Mede, Moor Road, Ashover, Chesterfield, Derbyshire, UK

\section{Abstract}

In 2013 this journal published the paper 'Integrity in Higher Education Marketing: A typology of misleading data-based claims in the university prospectus.' It argued that UK universities were using data and statistics in a misleading way in their advertising and proposed a nine-part typology to describe such claims. The present paper describes the subsequent responses in national media and academic writing. It then analyses recent developments in the regulation of university marketing in the UK, where the Advertising Standards Authority has publically rebuked universities and issued new guidance. Rulings against six UK universities are analysed and the paper considers the extent to which the new guidance addresses the nine types of misleading claims. The paper goes on to consider how issues such as this come to be addressed by regulators and what incentives will encourage universities to ensure the integrity of their marketing.

Keywords: Integrity, Higher education, Marketing, Marketisation, Prospectus, Advertising standards

\section{Introduction}

In 2013 this journal published the paper 'Integrity in Higher Education Marketing: A typology of misleading data-based claims in the university prospectus' (Bradley, 2013). The paper examined the misleading use of data and statistics by United Kingdom (UK) universities in their advertising and proposed a nine-part typology to describe such claims.

Type 1. Omission of material facts and selective reporting of data. This is a claim where the advertiser fails to disclose information or limiting conditions that are necessary for a correct interpretation of the claim.

Type 2. Misleading wording. These are claims where consumers may be misled by the use of confusing language which leads them to misunderstand the claim. It is described also as 'misleadingness due to semantic confusion'.

Type 3. Misleading inferences about an attribute. This is where a claim about an attribute leads to other, misleading, inferences about the same attribute.

(c) The Author(s). 2018 Open Access This article is distributed under the terms of the Creative Commons Attribution 4.0 International License (http://creativecommons.org/licenses/by/4.0/), which permits unrestricted use, distribution, and reproduction in any medium, provided you give appropriate credit to the original author(s) and the source, provide a link to the Creative Commons license, and indicate if changes were made. 
Type 4. Misleading associations between attributes. This is where a claim about one attribute encourages a belief about another attribute. The inference occurs because readers believe (rightly or wrongly) that the two attributes are correlated. Type 5. Misleading endorsements. This is where the advertiser appears to be presenting an endorsement or evidence from an independent source but the endorsement or evidence turns out not to be independent.

Type 6. Claim-fact discrepancy. This type of claim is one where, while literally accurate, some degree of qualification is required for it to be properly understood. Without such qualification the claim, while true, is misleading.

Type 7. Falsehoods. These are claims that are simply untrue.

Type 8 . The carefully crafted comparison. Often, claims are about a university's performance in comparison with other institutions. By carefully selecting the terms of that comparison it is possible to present a more favourable picture in a way that may be misleading.

Type 9. Claims without a reference point. Many claims offer data without any reference point for comparison. This makes them very difficult to evaluate and potentially misleading.

In a sample of $8 \mathrm{UK}$ prospectuses it found universities that:

- claimed accolades they had never been given

- recrafted league table data to put themselves at the top

- failed to mention related unflattering data

- used wording that was likely to be misleading

- implied endorsements they had not been given

- announced a department's 'excellence' based on a 19 year-old inspection report

- told outright lies

- quoted large figures for expenditure on resources or facilities but left readers unable to judge if these were exceptional or not.

The paper went on to suggest that 'the two bodies empowered to address this issue in the UK do not take a proactive approach and so it must fall to universities themselves to address the ethical challenges raised by misleading marketing.'

The present paper examines the immediate responses to the 2013 article in the UK media and subsequent academic contributions. It then considers recent developments in the approach of one of the UK regulatory bodies - the Advertising Standards Authority (ASA). It uses the 'typology' proposed in 2013 to assess the likely impact of these developments in regulation. The paper goes on to consider how issues such as this come to be addressed by regulators and what incentives will encourage universities to ensure the integrity of their marketing claims.

\section{Media response}

Times Higher Education, generally known simply as THE, is published weekly in London and reports on all aspects of international higher education. Following the publication of the 2013 paper, the author drew it to the attention of the editor of THE who then assigned a reporter to look at the story. The following week THE made the 
paper their lead article, featured on the front page and covered over two pages inside under the headline 'Rosy prospectuses 'misleading' students' (Mathews, 2014a). THE also publishes a weekly 'audio podcast' in which contributors discuss topics from the week's news. The 'misleading claims' paper was a lead item of the week's podcast. The back page of THE traditionally carries a satirical page written by a popular 'media academic' which describes events at the fictional 'University of Poppleton.' The subsequent edition of the University of Poppleton News described this establishment defending itself against accusations of misleading information in its prospectus and referenced the 'misleading claims' paper (Taylor, 2014).

Interestingly, THE chose to go further than the original paper. The paper had not named the universities in the research sample because any shortcomings identified in the integrity of these prospectuses are likely to be found more widely across the sector. As such, it seems unfair to name (and potentially shame) those institutions that were randomly selected for study.' However THE was able to match quotations in the paper to online prospectuses and thereby identify three of the universities in the sample. THE contacted the three universities to ask for a response. One explained that the misleading claim was 'an error of attribution' and would not be used again; one said that in future it would source all its data from the official Unistats website and one declined to comment on the grounds that '...the author recognised that it was unfair to name and potentially shame - those institutions that were randomly selected.'

The following week THE again made the paper a lead story. This time they focussed on the author's suggestion that: 'The two bodies with regulatory responsibilities in the field, Advertising Standards Authority (ASA) and Quality Assurance Agency for Higher Education, (QAA), do not take a proactive approach and have limited impact on the accuracy of university marketing materials.' Under the headline 'Are questionable marketing claims slipping past the watchdogs?' THE contacted the two regulators to seek their response to the suggestion (Mathews, 2014b).

A spokeswoman for the Advertising Standards Authority responded: 'The ASA relies largely on the public to bring misleading advertising to its attention. Although in areas such as gambling and alcohol advertising it proactively looks for problems without waiting for complaints, university marketing is not one of those priorities. We haven't, to date, received complaints about university prospectuses and complaint numbers about education marketing remain low.' However, she then provided THE with a list of 13 complaints the ASA had received about university marketing in a variety of media, 'which had been informally resolved with the university agreeing to amend or remove the claims instead of a full investigation being triggered and a ruling made.'

The Quality Assurance Agency responded through its Head of Standards who told THE that its guidance requires information for students to be fit for purpose, accessible and trustworthy.' She went on to say that QAA scours information on websites, student induction packs and prospectuses.' Interestingly the QAA spokeswoman went on to suggest that 'while there is no excuse for being misleading in prospectuses, prospective students will read it knowing it is a marketing tool.' This is a different view to that taken by the author, who argued that 'marketing from universities is not viewed as being 'advertising' by its adolescent recipients. Universities may be seen to be a reliable source of information and the prospectus as a 'factual account' of what the institution can offer. As such, university marketing may bypass the filter of scepticism through which young people typically perceive other advertisements.' 
The 2013 paper also received some attention in the mainstream press including the Daily Telegraph (Paton, 2014, Doughty, 2014), while The Guardian interviewed the author for a report on misleading university marketing (Young-Powell, 2014). Two student newspapers picked up the story (Hopkins, 2014; Sandbach, 2014), as did a number of education websites where news items are recirculated or simply plagiarised (Best Education News, 2014; Schools Improvement Net, 2014). Other non-academic appearances of the research included on the website of a company providing CRM (customer relationship management) software for student recruitment (Yeadon, 2014) and The Improving Dispute Resolution Advisory Service for Further and Higher Education (IDRAS, 2014). The Edge Foundation, an education charity, founded by former Secretary of State for Education Lord Baker, quoted the article as part of their manifesto arguing that too many young people are being encouraged in to higher education rather than pursuing potentially more rewarding routes to employment (Newton et al., 2017).

\section{Academic response}

In the academic literature Armstrong et al. (2014); Winter and Thompson-Whiteside (2015); Winter and Chapleo (2017); Simpson and Marinov (2016); Mogaji (2016); Rutter et al. (2017) all cited the paper but not in any attempt to pursue the question of misleading marketing. Five papers, however, did reference the research to take forward its key theme. Zapata and Tejeda (2016), drew on the study as part of a wide ranging review of misleading advertising by Chilean universities, arguing for greater state control, self-regulation and student empowerment. Almeida and Seixas (2016), in a Portuguese book, cited the research to make the point that fraud and plagiarism are not just matters to do with student and faculty behaviour, but are relevant to institutional behaviour as well. In a Russian study Makeyeva (2017) drew on the paper as part of her discourse analysis of the material for prospective students from 'unaccredited' Russian universities, concluding that in their communications 'advertising tactics' take precedence over useful information.

Interesting responses to the paper came from Gibbs (2014) and Gibbs and Aftab (2015). Gibbs has published a substantial body of work looking at questions of ethics and trust as they arise in the marketing of higher education (Gibbs, 2001, 2002;2004, 2007, 2012.) He has argued that there is an inherent contradiction in the notion of 'university marketing,' in that universities are expected to develop critical thinking while advertising seeks to manipulate rather than inform. 'In this sense it is the antithesis of education and acts as a counter to critical thought.' (Gibbs, 2007). In his 2014 paper Gibbs invoked the paper to question the use of data by universities - in particular the use of individual data analytics (data mining) which he suggested are employed to manipulate rather than inform students. In their 2015 paper Gibbs \& Aftab argued that universities have adopted marketing strategies 'best suited to selling chocolate, aspirin and supermarket discounts.' They quoted the nine categories of misleading claims and argued that tactics such as these represent a serious breach of trust in the relationship between institution and student.

\section{Anonymisation of the universities}

The 2013 paper did not name the universities in the research sample because any shortcomings identified in the integrity of these prospectuses are likely to be found more 
widely across the sector. As such, it seems unfair to name (and potentially shame) those institutions that were randomly selected for study.' The same decision has been taken in regard to universities discussed in this paper. The purpose of the paper is not to further 'name and shame' institutions but to discuss ethically questionable behaviours that are likely to have also been committed by other institutions.

\section{The advertising standards authority and committees of advertising practice}

'The Advertising Standards Authority (ASA) is the UK's independent regulator of advertising across all media. We apply the Advertising Codes, which are written by the Committees of Advertising Practice (CAP)' (ASA/CAP website).

The 2014 claim by the ASA, in their statement to Times Higher Education, that 'we haven't, to date, received complaints about university prospectuses', was surprising. In addition to the 13 complaints that ASA went on to list in their interview, this author had submitted complaints to the ASA. None of these had led to a full ASA investigation. It was therefore unexpected when a further complaint from the author in 2017 received the response from ASA:

'You may be interested to know, we have received several complaints about similar claims made about other universities. As we are already investigating other universities who are making similar claims and any findings would apply to all advertisers, we don't intend to investigate the [university newspaper advertisement] you are complaining about at this time.'

Things then moved quickly. In June 2017 several newspapers reported that University 1 had been instructed by ASA to stop using the claim that it is in the top $1 \%$ of world universities', (Pells, 2017,Weale, 2017, Harris, 2017). There was no formal ruling published on the ASA website, the matter having been 'resolved informally', However, from media reports it appears that the claim rested on the fact that they were ranked in the top 200 in the Quacquarelli Symonds (QS) World University Rankings. They then extrapolated from this that since there were believed to be more than 20,000 universities in the world, they must be within the top $1 \%$ in the world. ASA disagreed on the grounds that there was no assessment of all 20,000+ universities and as such the claim was 'not evidenced.' The university continued to defend their claim but agreed not to use it in the future. Their Head of Corporate Communications told The Guardian: 'We accept the ruling in relation to us but we've got scores of our competitors in UK and around the world who are making this claim. This has big implications for how UK universities are marketing themselves... we need a level playing field' (quoted in Weale, 2017.) Speaking to the Daily Mail he added, 'The ASA now needs to investigate every single other UK university which claims it is in the top one per cent in the world, rather than waiting for individual complaints to be made. It's odd if the ASA turns a blind eye to possible breaches of its own Code', (Harris, 2017.)

In terms of the typology of misleading claims, this claim is probably best categorised under type 8 'the carefully crafted comparison.' In this category are claims where the university starts with legitimate data but then stretches it or crafts it to make a more impressive claim, less well supported by the evidence. 
A few months later, in November 2017, several UK national news outlets reported that ASA was about to clamp down on misleading university advertising. 'Universities are going to face a crackdown on how they advertise and market courses to attract students,' said the British Broadcasting Corporation (BBC), (Coughlan, 2017). 'Universities accused of misleading students are braced for a clampdown from the advertising watchdog' reported The Times (Geddes, 2017.) 'The ASA is launching a crackdown on deceptive claims by higher education institutions' warned the Daily Telegraph, (Turner, 2017.) Some of these reports also included the news that two other universities had already been rebuked by ASA for misleading advertisements:

'The watchdog says [University 2] faced a complaint about claiming to have 'gold standard' teaching quality' when the university held a 'silver' award in the new teaching excellence framework. [University 3] was challenged over its claim to be 'university of the year.' It won the title in this year's 'Educate North' (regional) awards.' (Coughlan, 2017).

Neither of these cases led to a formal published ruling by ASA. If complaints are 'resolved informally' the advertiser agrees not to repeat the claims and no details of the investigation are published by the ASA.

The advance reports of a forthcoming 'crackdown' were presumably prompted by news agencies having early notice of what was to come. As predicted, a week later ASA published rulings against six universities for misleading advertising (Harding, 2017, Sweney \& Weale, 2017) These rulings were accompanied by a new set of guidance 'Universities: Comparative claims' (ASA/CAP, 2017a) and more informal suggestions on how to comply: 'Top tips for making comparative claims in the higher education sector,' (ASA/CAP, 2017b.)

The next section of this paper considers the six university advertisements judged to have fallen foul of advertising standards and the new ASA guidance. It describes the complaints and the ASA judgements and classifies these in terms of the nine part typology, in order to establish the scope of the new guidance.

\section{University 4}

The complaint

ASA received two complaints about a paid Facebook post in which the university described itself as 'a top $1 \%$ world university.' The issue was similar to the claim by University 1 cited earlier.

\section{The ruling}

In this case there was debate between the ASA and the university as to how many universities existed in the world. In University 4's case there needed to be about 26,000 universities in the world for their position in the QS World Rankings to place them in the top $1 \%$. In their ruling, the ASA 'did not consider the figure (of numbers of universities in the world) to be substantiated. In the absence of qualification about the basis of the claim and adequate substantiation, we considered the ad to have exaggerated the level of the university's relative standing worldwide, and therefore was likely to mislead.' (ASA, 2017f). The university was told to stop using the claim and agreed to do so. 
Typology

ASA appear to have rejected University 4's assertion of being a 'top 1\%' university on somewhat different grounds to their rejection of University 1's identical claim. ASA's grounds for rejection here are probably closer to type 7 'falsehoods' where the claim is judged to be simply untrue.

\section{University 5}

The complaint

ASA received two complaints, ('one from an academic') regarding claims on their website and in their prospectus that they were “The UK's No.1 Arts University (for three years running) in The Sunday Times League Table 2017" and "The UK's number one Creative University in The Sunday Times League Table 2017, Guardian University Guide 2017 and Complete University Guide 2017". The complainants pointed out that there were other higher ranking universities offering creative and arts courses,

\section{The ruling}

The university told ASA that their claims referred to a sub-set of five universities (including themselves) with a focus on the arts. ASA judged that there was no evidence that the sub-sets "Arts Universities" or "Creative Universities" had been publically defined and ranked by any of the university league tables. 'We also considered that other universities that were likely to be reputable for their art and creative courses were not included within this sub-group referred to by [University 5].' and 'we considered that these "No.1" rankings were generated through narrowing down the pool of competitors from the overall league tables which included all other institutions, and there did not appear to be separate groups of defined "Arts" or "Creative" universities in these league tables.' The university was told to stop using the claims and agreed to do so (ASA, 2017a).

\section{Typology}

This example demonstrates aspects of type 5 - 'misleading endorsements.' The university was claiming that it was endorsed as No.1 Arts or Creative University by a number of league tables. However their pre-eminence was in a league table they had created themselves. The author's 2013 research found 'many examples where claims appear to invoke an independent endorsement but which turn out to be based on the university's own manipulation of data.'

\section{University 6}

\section{The complaint}

The University described itself as 'Top university in England for long-term graduate prospects. Government longitudinal outcomes data 2016.' A complainant challenged that claim, suggesting that the cited government data indicated that average earnings of Cambridge University graduates after 5 years were higher than those of graduates from University 6. 
The ruling

The university argued that their claim rested on Higher Education Statistics Agency (HESA) data showing that $84.9 \%$ of their graduates were in employment or further study after 5 years. This was the highest figure for an English university, on that measure. ASA accepted this point but noted that on other measures in the same table - employment/study rates after 1 year and 3 years, University 6 was not at the top. ASA also noted other tables in the same HESA data set that looked at graduate earnings, where the university did not out-perform all other universities (ASA, 2017b).

\section{Typology}

This would seem to fit type 2 'Misleading wording' - described also as 'misleadingness due to semantic confusion' - claims where the use of confusing language leads readers to misunderstand the claim. In this case the potentially confusing wording was 'long term-graduate prospects.' As ASA remarked, many readers of that phrase might assume it included some measure of graduate earnings and not simply a measure of the percentage of graduates in employment or study at one particular audit point. ASA ruled that the university must not use the claim in future marketing.

\section{University 7}

The complaint

'An academic' complained to ASA about the university's webpage titled "Physics" with a headline stating "We're ranked No.1 in the UK" and "The Department of Physics at [University 7] ... has been rated number one in the UK for research in the REF 2014".

\section{The ruling}

The ASA considered the average consumer would interpret the claim to mean the university had been ranked by the Research Excellence Framework (REF) 2014 as the top performing physics department in the UK for research. As the 2013 paper observed, ffor all its other shortcomings, the research assessment exercise did not actually 'rank' universities or departments by creating a hierarchical table of results.' That is left to the publishers of the various university league tables who apply their own calculations to the data to create 'league tables'. ASA commented that 'one could choose a number of different ways to 'rank' the listed universities depending on the chosen methodology.' They went on: 'We therefore considered that the ad should have made clear that the basis of the "No.1" claim was the ranking by the Times Higher Education rather than the REF 2014. Because the ad misleadingly implied the REF 2014 had ranked the university as the top performing physics department, we concluded that the ad was misleading' (ASA, 2017d).

\section{Typology}

This appears to be an example of type 5 - 'Misleading endorsements.' The 2013 paper commented: 'as Dean and Biswas (2001), have demonstrated, third party endorsements are a particularly persuasive strategy for increasing perceptions of 'quality'. As such, universities' strategies to present 'rankings' as if they were calculated as part of an 
independent, government mandated review, rather than by a newspaper, are potentially misleading.

\section{University 8}

The complaint

ASA received a complaint after the university described itself as "Top 5 for student satisfaction (National Student Survey 2005-2016.)" The complainant did not believe this to be true.

\section{The ruling}

The university explained that it had 'used an internal reporting tool to generate the statistic.' The university had re-worked the National Student Survey (NSS) data and removed universities that they did not consider to be 'mainstream.' They had also removed Scottish, Welsh and Northern Ireland universities, thereby creating their own league table of what they considered 'mainstream English universities.' ASA examined the data and concluded that even within this self-generated category, the university did not fall in the 'top 5' from 2005 to 2016, as claimed, being ranked 9th in 2016 (ASA, 2017c).

\section{Typology}

This appears to be an example of type 8, 'The carefully crafted comparison', of which the author's earlier research said: 'Many claims are about a university's performance in comparison with other institutions. By carefully selecting the terms of that comparison it is possible to present a more favourable picture in a way that may be misleading.'

\section{University 9}

The complaint

The university claimed it had been "named as London's top modern university - and one of the top 10 in the UK - in the Guardian University Guide 2018". A complainant challenged whether this was true.

\section{The ruling}

The university said that the claim was based on their ranking in the Guardian University Guide 2018, (in which they were positioned 58th.) They then identified what they regarded as the other 'modern' universities in the UK in the University Guide and deduced that they were ranked ninth overall within this, self-chosen, pool. As part of this strategy they had to remove four modern universities that they felt 'were different in character to the group,' having a history in art and teacher training. All these four were above the university in the rankings and so their removal lifted the university from 13th to 9th place.

ASA judged that while 'The university's claim was based on the results of the published Guardian University Guide 2018... it was [the university] that had concluded that it was in the top ten modern universities in the UK by narrowing the pool of other institutions based on their definition of a modern university. We therefore considered it was misleading (ASA, 2017e). 


\section{Typology}

This appears to be another example of type 8, 'The carefully crafted comparison', where universities re-work legitimate data to eliminate some other institutions and inflate their own status.

\section{New ASA/CAP guidance}

On the same day that these six rulings were published ASA/CAP issued new guidance: 'Universities: Comparative Claims'(ASA/CAP, 2017a) and the more informal 'Top tips for making comparative claims in the university sector'(ASA/CAP, 2017b). The new guidance does not introduce any new 'rules' for advertisers but rather it spells out the implications of long-standing ASA/CAP regulations for university marketing claims. As can be seen from the titles, the focus is on 'comparative claims.' In brief, ASA/CAP told universities:

- If a claim is likely to be interpreted as objective, you 'must hold robust evidence to substantiate it'

- make the basis of the claim clear and include any necessary qualifications. Do not use ambiguous terms such as 'modern university' unless you clarify what you mean.

- do not exaggerate or go further than the evidence you hold

- only refer to categories or information contained in the relevant league table or report. Do not present claims with a further layer of your own analysis or categorisation of results

- do set out the evidence for claims or signpost the reader to where they can verify the claim for themselves.

\section{The new ASA/CAP guidance as a response to misleading university advertising}

From the previous analysis we can see that the recent ASA rulings have dealt with misleading advertisements that can be regarded as fitting four of the typology's categories:

- Type 2 Misleading wording, (University 6)

- Type 5 Misleading endorsements, (Universities 5 and 7)

- Type 7 Falsehoods (Universities 2, 3 and 4)

- Type 8 The carefully crafted comparison, (Universities 1, 8 and 9)

It should be no surprise that an advertising regulator deals with 'falsehoods' but their rulings on misleading wording, misleading endorsements and carefully crafted comparisons demonstrates a more nuanced approach to what constitutes 'misleading.' Their guidance on 'the carefully crafted comparison' in particular, addresses an issue that the author's earlier paper suggested was common in the genre.

This leaves five of the typology's categories unrepresented in recent ASA/CAP developments. In order to explore whether these five other types of misleading advertisement are still to be found, the prospectus and website of each of the nine universities cited by ASA were examined. This search provided evidence that the 9 part typology still provides a useful lens through which to examine misleading university marketing. 


\section{Type 1. Omission of material facts and selective reporting of data}

This is a claim where the advertiser fails to disclose information that is necessary for a correct interpretation of the claim.

Example: University 4's website has a section titled 'Facts, figures and rankings' which tells readers:

'Our teaching: 'We are proud to be renowned for our teaching, research and broadening access to higher education. The Teaching Excellence Framework (TEF) has been introduced by the government to recognise and reward high quality teaching in higher education. The purpose of this new framework is to provide students with clear information about which of England's universities are providing good quality teaching.'

Strangely, for a section devoted to 'facts, figures and rankings', the page does not go on to tell the reader about the university's grading in the TEF, (it was awarded 'Silver' the middle tier ranking.) Instead there is a statement from the President and Vice Chancellor, "We are committed to giving our graduates that extra dimension - a degree from a leading institution coupled with an inquisitiveness and sharpness of mind to ensure they continue to excel."

The university's claim 'Facts, figures and rankings...our teaching...we are proud to be renowned for our teaching...' followed as it is by a description of the TEF process, would logically lead to a mention of the university's grading in the TEF process. The omission of that information, and instead putting in a statement praising the universities qualities, seems to be an 'omission of material facts and selective reporting of data.'

\section{Type 3. Misleading inferences about an attribute}

This where a claim about an attribute leads to other, misleading, inferences about the same attribute.

Example: A University 2 webpage headed 'Award winning university' proclaims: 'both our academics and our professional support staff have won major awards for their work'. Lower down the page is a list of awards in chronological order, the most recent being for 2014. All three awards listed for 2014 were for university marketing and 13 of the university's 17 awards in the decade 2008-17 were for marketing or public relations activity.

A reader seeing that university claims the attribute 'award winning university', might make the inference that these awards were for attributes relating to educational activity - teaching, learning or research. In part, that inference would be misleading.

\section{Type 4. Misleading associations between attributes}

Here, a claim about one attribute encourages a belief about another attribute. The inference occurs because readers believe (rightly or wrongly) that the two attributes are correlated.

Example: University 7 claims in their 2018 undergraduate prospectus that ' $11 \%$ OF ALL NOBEL PRIZES HAVE BEEN AWARDED TO SCOTSMEN.' To recognise the meaning of this (capitalised) claim we need to see it in context. The prospectus is 
encouraging young people to apply to the university. Their prospectus, like all others, is packed with claims about the facilities, teaching and research at the university. So readers are being invited to perceive a link between this claim and the university. In fact none of the 585 Nobel Prizes awarded between 1901 and 2017 were awarded to anyone with a link to University 7. Since it also appears that just 13 Nobel prizes have been awarded to Scotsmen $-2.2 \%$, the claim not only creates 'a misleading association between attributes,' but is also untrue (Nobel Prize, 2018).

\section{Type 6. Claim-fact discrepancy}

This type of claim is one where, while in some sense accurate, a degree of qualification is required for it to be properly understood. Without such qualification the claim is misleading.

Example: University 3 claim in their 2018 undergraduate prospectus:

'In 1957 John Lennon joined [University 7's] School of Art and Design and it was to provide the springboard for so many influential aspects of his life.'

Since the university was not established until 1992, this seems unlikely. In fact he joined the local College of Art, and according to Spitz, (2005) he was 'thrown out of college before his final year' because of his disruptive behaviour. So a more accurate reference might be 'In 1957 John Lennon joined the local College of Art, 35 years before the founding of the university. However he was expelled before finishing his course.'

\section{Type 9. Claims without a reference point}

Many claims offer data without any reference point for comparison. This makes them very difficult to evaluate and potentially misleading. These claims seem to evade the ASA regulations on 'comparative claims' by not explicitly comparing their university to any other establishment. The impression that their data is in some way noteworthy is achieved by implication.

This type of claim still seems to be ubiquitous in the university prospectus.

Examples: 'E4.6 million awarded annually in scholarships, prizes and hardship funds,' (University 3). Is that a larger than average amount for a university?

'We've invested over $£ 270 m$ in our town-centre campus', (University 6). Over what period of time was the money spent? Is that a big annual investment?

'The Technology \& Innovation Centre is over 25,000 square metres - equivalent of 100 tennis courts', (University 7). Is that a big building or just average for its type?

'800,000+ volumes of books and journals' (University 8). Is that typical for a university or a particularly large collection?

'A library with over two kilometres of book shelving, (University 9). Again, is that a lot of shelving? (And is it just the shelving or are there books?)

The recent ASA rulings, highly publicised as they were, provided a strong message to UK universities about ensuring the truthfulness of their marketing claims. The new ASA/CAP guidance further reinforced this and set out clear advice on what universities should and should not do.

However, the foregoing analysis suggests that there are some potentially misleading types of advertisement that may not be picked up by the new ASA/CAP approach. 
These generally seem to be the more 'subtle' examples of wording or formulation that while often technically true, have the possibility of misleading.

\section{Reflections on 'misleading university marketing' as an example of identifica- tion and engagement with a 'social problem'}

In her recent paper in this journal Downes (2017) looked at the impact of 'scandals' of different types on university reputation and discussed how universities should take steps to prevent these image-damaging events. The universities publically 'named and shamed' by the ASA in November 2017 probably suffered much more modest damage to their reputation than the universities involved in Downes' scandals. Nevertheless, having reports of your misleading marketing appear in the national press and the $\mathrm{BBC}$ can only raise public concerns about the integrity of universities. As Gibbs and Aftab (2015) argue, misleading marketing is a serious breach of trust in the relationship between institution and student.

Downes draws on social constructionist sociology to consider the process by which issues emerge as a 'problem' and come to be dealt with. This model of 'the construction of social problems', originally formulated by Spector and Kitsuse (2001) suggest that examples of improper behaviour are ubiquitous in society. For much of the time these are ignored or tolerated. Then at some point someone or a group acts to draw attention to the issue. If this 'whistleblowing' is then picked up and amplified, typically by the media, then institutions with power to do something are driven to act.

This model also seems to fit the issue of misleading university marketing. In the author's earlier paper (Bradley, 2013), the literature review identified numerous writers, over many years, who had expressed awareness of misleading marketing in the higher education sector. So this was not some secret, unknown issue. Rather it was an issue of educational integrity, of which there was widespread awareness in the sector. When the 'typology' paper was then picked up and amplified by commentators in the media - most notably in the THE, it became openly discussed, albeit briefly, as 'a problem.'

This 'problem' was then acknowledged by one of the organisations with the power to do something about it. In the run-up to the November 2017 ASA/CAP guidance it seems that ASA ensured that national media was aware that there was 'an issue' by revealing that they had already dealt 'informally' with three universities. As such they were priming the press and public to be aware that this was an issue of concern. Charles Heyman was Head of Corporate Communications at one of the universities at the time of the ASA enquiry in to their marketing but left shortly afterwards. Describing those events in his blog (Heyman, 2017), he says 'It was a fair cop and the only option was to hold our hands up and phase it out.' However, he goes on to describe the reaction of some of his peers in university marketing: 'my comments in the national media caused quite a stir with various irate competitors privately criticising us for opening Pandora's Box.' The 'Pandora's box' metaphor seems an apt one to describe the transition from 'a secret lots of people know about' to a publically debated social issue about the honesty of UK higher education in its dealing with potential students.

\section{Discussion}

The ASA and CAP have taken measured and proportionate action to draw attention to misleading university marketing. By bringing nine examples to public attention and issuing guidance to the sector they have made clear what they believe universities can and cannot claim. They have also helpfully reframed the issue by emphasising that to 
decide what is potentially 'misleading' you need to think from the perspective of what a typical reader might understand by the message, not what the writer intended.

Against this backdrop of new guidance though, we must remember that there are more than 130 universities and many other higher education (HE) institutions in the UK. Each of these publishes advertising material through websites, social media, prospectuses, print and broadcast media. In the random sample for the author's 2013 paper there were an average of 116 data based claims per prospectus this was without even looking at websites or social media. So we could be talking about more than 15,000 'data based claims' a year, just in the printed prospectuses of mainstream universities. It does not seem reasonable to expect an organisation such as ASA, with responsibilities across the whole range of consumer issues, to pro-actively police university marketing.

ASA/CAP have done what seems reasonable - rebuked some universities publically and published clear guidelines. It must be for others to ensure that university marketing demonstrates the level of honesty and integrity expected in other aspects of scholarly activity.

Universities themselves must take responsibility for monitoring the truthfulness of what their marketing departments are doing and saying on their behalf. In 2014, shortly after THE had published lead stories on the issue for two consecutive weeks, the Committee of University Chairs (CUC) issued new draft guidance on university governance. This appeared to respond directly to concerns about misleading advertising and required that:

'The governing body should ensure the publication by the institution of accurate and honest information about its activities which avoid false or exaggerated claims. This is particularly important in relation to information for prospective students.'

(Committee of University Chairs, 2014a).

Sadly, this very clear directive was removed after consultation with CUC members. In its place the final version contained the rather more general suggestion that governing bodies should:

'Receive assurance that its publications provide accurate and honest information about its activities.'(Committee of University Chairs, 2014b).

The reference to 'false or exaggerated claims' was removed, as was the reference to this being 'particularly important in relation to information for prospective students.' This is regrettable. It is really only universities themselves that are in a position to ensure honesty and integrity in their marketing. The marketing of universities was once a rather quiet activity, led by academics (Brockbank, 1996) but is now the territory of professional advertising and marketing staff (Steele, 2007). University senior managers, or failing that, governing bodies, are in a position to guide and monitor what is published on their behalf. It must be hoped that despite the less specific wording in their new code of governance, university governing bodies take the issue seriously and actively engage with the output of their marketing departments. The effectiveness, or otherwise, of the new CUC governance code could helpfully be the focus of future research. 
On a more positive note, the engagement of students with the issue has been an encouraging development. Several student newspapers and websites picked up on the November 2017 ASA rulings. Typically they took a critical view of what universities had been doing. 'False advertising has real consequences' said Durham University's Gryphon newspaper. 'Universities have been rumbled for misleading ranking claims' reported International Student and 'Good! Universities to face fines over adverts that mislead students' was the headline on graduate student website Graduate Frog.

Probably the most impressive response in this field came from SCAN, the student newspaper at Lancaster University. Not only did they report the ASA rulings but they used them as a springboard to publish their own investigation in to misleading advertising by their university (Callender, 2017.)

This student engagement with the issue serves to remind us why this is important. Fees and living expenses at English universities mean that the average student will graduate with over $£ 50,000$ of debt (IFS, 2017.) The UK's successful moves to widen participation in HE mean that many new students come from backgrounds where there is limited knowledge of universities (Pugsley, 2004; Kintrea et al., 2011). As such, the information in prospectuses and on websites may be the principal source of evidence for many students' choices.

With this in mind we can see a number of reasons why universities should take misleading marketing seriously. At the most practical level, in the marketised university world, it is a matter of consumer law that universities tell the truth to young people about to spend a large sum of money with them. Indeed the UK Competition and Markets authority recently reminded universities that consumer protection law will generally apply to the relationship between HE providers and prospective and current students.' In the UK this means that 'the information (you provide) should be accurate, clear and unambiguous ... and you should not omit important information.' (Competition \& Markets Authority, 2015).

If complying with the law is not a sufficient motivation to avoid misleading advertising, then the damage to a university's reputation when found out and 'named and shamed' should be a powerful reason to discourage poor behaviour (Downes, 2017.)

One would hope of course, that universities would behave with integrity because they believed it was ethically the right thing to do. Gibbs and Murphy (2009), propose a model for higher education marketing based on ethical values. This requires that all those involved understand the ethical framework of their profession; that institutions articulate their values and principles and provide ethical codes to guide decision making and that the institution cultivates a culture where leaders make clear the moral as well as the academic and financial aims of the organisation. It may be that the UK's newly established Office for Students (OfS) will have a role to play in reminding university managers and governors of their duty of truthfulness.

Beach (2005) suggests that it is usually a mixture of instrumental reasons (bad publicity, fines, reputational damage) and normative reasons (recognising it is ethically the right thing to do) that drive institutions' compliance with regulations.

If neither consumer protection law, reputational risk nor ethical considerations are persuasive then Guy Parker, the Chief Executive of the ASA posted a tweet 
that nicely encapsulates one further line of reasoning. Commenting on his organisation's recent rulings he posted:

\section{'Important message for unis: practice what you teach by making sure your ad claims are backed up.'}

In their scholarly work, universities recognise the need for accuracy, evidence and the careful presentation of information. The same characteristics should be apparent in their marketing as well. At a time when notions of 'fake news' and 'alternative facts' have led some to speak of a 'post-truth era', universities must continue to provide models of honesty and integrity.

\section{Abbreviations}

ASA: Advertising standards authority; BBC: British broadcasting corporation; CAP: Committees of advertising practice: CUC: Committee of University Chairs; HESA: Higher education statistics agency; IDRAS: Improving dispute resolution advisory service for further and higher education; IFS: Institute for fiscal studies; NSS: National student survey; OfS: Office for students; QAA: Quality assurance agency for higher education; QS: Quacquarelli symonds; RAE: Research assessment exercise; REF: Research excellence framework; TEF: Teaching excellence framework; THE: Times higher education; UK: United Kingdom

\section{Acknowledgements}

The author is grateful to staff at the UK Advertising Standards Authority (ASA) who provided helpful comments on an early draft of this paper.

\section{Authors' contributions}

The author is the only person involved in producing this paper. The author read and approved the final manuscript.

\section{Authors' information}

John Bradley has worked as an educational psychologist in England, Hong Kong and Brunei. He was Principal Educational Psychologist and Head of Social Inclusion for Nottinghamshire County Council in England, prior to his retirement. He completed his doctorate at the University of Nottingham as a (very) mature student, examining young people's ideas of 'going to university'. He now works part-time with university students with additional needs and undertakes independent research into university recruitment.

\section{Competing interests}

The author declares that he has no competing interests.

\section{Publisher's Note}

Springer Nature remains neutral with regard to jurisdictional claims in published maps and institutional affiliations.

Received: 6 March 2018 Accepted: 4 June 2018

Published online: 11 June 2018

\section{References}

Almeida F, Seixas A (2016) Fraude e plágio na Universidade: a urgência de uma cultura de integridade no Ensino Superior:Fraud and Plagiarism at the University: The urgency of a culture of integrity in higher education. Coimbra University Press, Coimbra

Armstrong A, Johnson MA, Smith M, Thomas J (2014) Consumerism in higher education: pressures and faculty conformity. J Cross-Disciplinary Perspect Educ 7(3):1-9

ASA (2017a) Advertising Standards Authority Ruling on Complaint Ref: A17-390070. Retrieved January 19, 2018, from https://www.asa.org.uk/rulings/falmouth-university-a17-390070.html

ASA (2017b) Advertising Standards Authority Ruling on Complaint Ref: A17-395184. Retrieved January 19, 2018, from https://www.asa.org.uk/rulings/teesside-university-a17-395184.html

ASA (2017c) Advertising Standards Authority Ruling on Complaint Ref: A17-390154. Retrieved January 19, 2018, from https://www.asa.org.uk/rulings/university-of-east-anglia-a17-390154.html

ASA (2017d) Advertising Standards Authority Ruling on Complaint Ref: A17-390134. Retrieved January 19, 2018, from https://www.asa.org.uk/rulings/university-of-strathclyde-a17-390134.html

ASA (2017e) Advertising Standards Authority Ruling on Complaint Ref: A17-393188. Retrieved January 19, 2018, from https://www.asa.org.uk/rulings/university-of-west-london-a17-393188.html

ASA (2017f) ASA Ruling on Complaint ref: A17-393534. Retrieved January $19^{\text {th }} 2018$ from https://www.asa.org.uk/ rulings/university-of-leicester-a17-393534.html

ASA/CAP (2017a) Universities: comparative claims: advice. The advertising standards authority London UK Retrieved from https://www.asa.org.uk/advice-online/universities-comparative-claims.htm 
ASA/CAP (2017b) Top tips for making comparative claims in the higher education sector. The advertising standards authority London UK Retrieved from https://www.asa.org.uk/news/top-tips-for-making-comparative-claims-in-thehigher-education-sector.html

Beach D (2005) Why governments comply: an integrative compliance model that bridges the gap between instrumental and normative models of compliance. J Eur Public Policy 12(1)

Best Education News (2014) Do university prospectuses mislead college students? Retrieved from http://www. besteducationnews.com on 6th June 2014.

Bradley J (2013) Integrity in higher education marketing? A typology of misleading data-based claims in the university prospectus. Int J Educ Integr 9(2):74-88 Retrieved from: https://www.ojs.unisa.edu.au/index.php/IJEl/article/view/894

Brockbank L (1996) Prospectus perspectives. Educ Market 5:16-18

Callender S (2017) The best in the UK? Questions over university marketing claims. In: SCAN Lancaster University Student Newspaper, (6th December)

Committee of University Chairs (2014a) Consultation: Higher Education Code of Governance 24th February 2014. Committee of University Chairs, Bristol

Committee of University Chairs (2014b) The Higher Education Code of Governance Committee of University. Chairs, Bristol

Competition \& Markets Authority (2015) UK higher education providers - advice on consumer protection law. In: Helping you comply with your obligations, London

Coughlan S (2017) Universities to be warned over misleading adverts. BBC News Website, London

Doughty E (2014) University prospectuses: the pursuit of pretty pictures. In: The daily telegraph 21st January 2014 London

Downes M (2017) University scandal, reputation and governance. Int J Educ Integr 13(1):8 https://doi.org/10.1007/ s40979-017-0019-0

Geddes D (2017) Universities warned not to bend the truth in their advertising. In: The Times 10th November 2017 London

Gibbs P (2001) Higher education as a market: a problem or solution? Stud High Educ 26(1)

Gibbs P (2002) From the invisible hand to the invisible handshake: marketing higher education. Research in PostCompulsory Education 7(3):325-338 https://doi.org/10.1080/13596740200200134

Gibbs P (2004) Trusting in the university: the contribution of temporality and trust to a praxis of higher learning. Springer Science \& Business Media, Berlin

Gibbs P (2007) Does advertising pervert higher education? J Mark High Educ 17(1):3-11

Gibbs P (2012) The commoditization and standardization of higher education. In: Maringe F, Foskett $N$ (eds) Globalization and internationalization in higher education: theoretical, Strategic and Management Perspectives. Bloomsbury T \& T Clark, London

Gibbs, P. (2014). Privacy, analytics and marketing higher education. In Meno M, D. G. Terkla, \& P. Gibbs (Eds.), Using Data to Improve Higher Education. Springer. Retrieved from https://link.springer.com/book/ 10.1007/978-94-6209-794-0

Gibbs P, Aftab D (2015) Do higher education institutes communicate trust well? J Mark High Educ 25(2)

Gibbs P, Murphy P (2009) Implementation of ethical higher education marketing. Tert Educ Manag 15(4): 341-354 https://doi.org/10.1080/13583880903335472

Harding E (2017) Six university adverts that misled undergraduates about career prospects, rankings and student satisfaction are banned by watchdog. In: Daily mail, London UK $15^{\text {th }}$ November 2017 Retrieved from http://www.dailymail.co.uk/news/ article-5083489/Six-university-adverts-misled-undergraduates.html

Harris, S. (2017). UK universities "can"t say they're in the top 1\%'. Daily Mail 9th June 2017. Retrieved from http://www.dailymail.co.uk/news/article-4586880/UK-universities-t-say-1.html

Heyman, C. (2017). University branding needs a radical gear shift. Retrieved January 19, 2017, from http://wonkhe.com/ blogs/university-branding-needs-a-radical-gear-shift/

Hopkins C (2014) University prospectus misinforms students. In: The Hullfire (University of Hull Student Newspaper) 4th February 2014

IDRAS (2014) Was the prospectus honest with you? In: Improving Dispute Resolution Advisory Service for Further and Higher Education Retrieved June 9, 2014, from http://www.idras.ac.uk/did-this-happen-to-you/student-stories/didntyou-get-what-was-promised-in-the-course-advertisement/did-your-provider-break-promises-about-the-course/

IFS (2017) Higher Education Funding in England: Institute for Fiscal Studies Briefing note 211. Published by Institute for Fiscal Studies, London

Kintrea K, St Clair R et al (2011) The influence of parents, places and poverty on educational attitudes and aspirations. Joseph Rowntree Foundation, York, UK

Makeyeva SO (2017) Commercialized academic discourse - advertising practices of non-accredited universities. Педагогическое Образование В России Pedagogical Educ Russia 10:31-40 Retrieved from https:/cyberleninka.ru/ article/n/akademicheskiy-reklamnyy-diskurs-obzor-publikatsiy-i-sotsialnaya-gran-reklama-vuzov-lishennyh-akkreditatsii

Mathews D (2014a) Rosy prospectuses "misleading" students. In: Times Higher Education, (January 16 2014) Retrieved from https://www.timeshighereducation.com/news/rosy-prospectuses-misleading-students/2010522.article

Mathews D (2014b) Are questionable marketing claims slipping past the watchdogs ? In: Times Higher Education, (January 23 2014)

Mogaji E. (2016). University website Design in International Student Recruitment: some reflections. In Wu T., Naidoo V. (eds) International Marketing of Higher Education. Palgrave

Newton, O., Laczik, A., \& Percy, C. (2017). Our plan for Higher Education. The Edge Foundation, London UK retrieved from http://www.edge.co.uk/OurPlanforHE on January $19^{\text {th }} 2017$

Nobel Prize (2018) Nobel prize facts. Nobel Prize Organisation, Stockholm Retrieved from https://www. nobelprize.org/nobel_prizes/facts/

Paton G (2014) Universities bend the facts in dodgy student prospectuses. In: Daily Telegraph January 16 2014 Retrieved from http://www.telegraph.co.uk/education/universityeducation/10577237/Universitiesbend-the-facts-in-dodgy-student-prospectuses.html 
Pells R (2017) Reading university under fire after claiming to be in top $1 \%$ in the world. In: The independent 8th June 2017 London UK

Pugsley L (2004) The university challenge: Higher education markets and social stratification. Ashgate, Cardiff

Rutter R, Lettice F, Nadeau J (2017) Brand personality in higher education: anthropomorphized university marketing communications. J Mark High Educ 27(1):19-39 https://doi.org/10.1080/08841241.2016. 1213346

Sandbach W (2014) Should you believe everything in a university's prospectus? In: Expose : The University of Exeter Student Newspaper 24th January 2014, pp 4-7

Schools Improvement Net. (2014). Do university prospectuses mislead students ? Retrieved June 7, 2014, from https:// schoolsimprovement.net/do-university-prospectuses-mislead-students/?utm_sou

Simpson C, Marinov M (2016) University Autonomy in the Age of Marketization. In: Turcan RV, Reilly JE, Bugaian L (eds) (re)discovering university autonomy. Palgrave Macmillan, New York, p 73 Retrieved from https://link.springer.com/ chapter/10.1057\%2F9781137388728 5

Spector M, Kitsuse J (2001) Constructing social problems. Taylor and Francis, Abingdon

Spitz R (2005) The Beatles: A Biography. Little, Brown, London

Steele K (2007) Standing out on paper: Best practices in university viewbooks. In: Paper presented to Atlantica Association of Registrars and Admissions Officers, Fredericton. NB Canada

Sweney M, Weale S (2017) Six UK universities break advertising rules with pitches to students. In: The Guardian 15th November 2017 London

Taylor L (2014) Damn lies and prospectuses. In: Times Higher Education 23rd January 2014

Turner C (2017) Universities under investigation by advertising watchdog for misleading students. The Daily Telegraph 10th November 2017. Retrieved from http://www.telegraph.co.uk/education/2017/11/10/universities-investigationadvertising-watchdog-misleading-students/ on 11th November 2017

Weale S (2017) Advertising watchdog forces reading university to ditch top 1 \% claim. The Guardian 8th June 2017, pp. 8-10 Published by Guardian Media, London

Winter E, Chapleo C (2017) An exploration of the effect of servicescape on student institution choice in UK universities J Furth High Educ 41(2):187-200 https://doi.org/10.1080/0309877X.2015.1070400

Winter E, Thompson-Whiteside H (2015) How the city works its magic: the contribution of location to the higher education servicescape. In Proceedings of the Academy of Marketing Conference - the magic in marketing 7th July 2015 University of Limerick Retrieved from http://programme.exordo.com/am2015/delegates/presentation/ 176/ on 4th March 2018

Yeadon D (2014) Flattering prospectuses mislead students. Retrieved from http://www.student-crm.co.uk/blog-page-1/ flattering-prospectuses-mislead-students

Young-Powell A (2014) Do university prospectuses mislead students? The Guardian 6th June 2014 London. Retrieved from https://www.theguardian.com/education/2014/jun/06/do-university-prospectuses-mislead-students

Zapata G, Tejeda I (2016) Misleading advertising in higher education: definitions, regulations, and a review of written press advertising. Calidad En La Educación 44:197-242 https://doi.org/10.4067/S0718-45652016000100008

Submit your manuscript to a SpringerOpen ${ }^{\odot}$ journal and benefit from:

- Convenient online submission

- Rigorous peer review

- Open access: articles freely available online

- High visibility within the field

Retaining the copyright to your article

Submit your next manuscript at $>$ springeropen.com 